\title{
The Development of Image Media Based on Problem Based Learning to Grow Communication Skills on Second Grade of Elementary School
}

\author{
Novita Veronica ${ }^{1 *}$ Herpratiwi $^{2} \quad$ Alben Ambarita $^{3} \quad$ Darsono $^{4}$ \\ Faculty of Teacher Training and Education, University of Lampung \\ St. S. Brojonegoro, No.1, Gedung Meneng, Bandar Lampung, Indonesia, 35145
}

\begin{abstract}
The purpose of this research and development is to develop and describe the feasibility and effectiveness of developing image media based on Problem Based Learning products to improve student learning communication. This type of research and development refers to Borg and Gall theory. The sample was determined by purposive sampling of 16 students of second-grade at Darma Bangsa Elementary School. Data were collected through observation sheets, questionnaires, and test questions. The data analysis technique used the n-Gain test to determine the effectiveness of the results obtained, namely 0.488 . The results of the validation of image media based on Problem Based Learning are done by material, design and media experts. The results showed that, product development based on Problem Based Learning that is produced effectively is used in the learning process for second-grade students. This is evidenced by the increase in student learning outcomes and student communication skills after using Problem Based Learning based on image media.
\end{abstract}

Keywords: image media, Communication Skills, Problem Based Learning

DOI: $10.7176 / \mathrm{JEP} / 11-3-06$

Publication date: January $31^{\text {st }} 2020$

\section{INTRODUCTION}

The development of the 21 st-century world is characterized by the use of information and communication technology in all aspects of life, including in the learning process. Conceptually, Educators as professional staff must fill various competency requirements to carry out their duties and authorities in a professional manner, while the reality on the ground is still very alarming, both in quantity, quality and professionalism. This problem is still compounded by various challenges ahead that are still complex in the global era. The loss of boundaries between space and time in interactions between individuals in the era of globalization requires the ability to interact and communicate effectively and efficiently. The learning process is a mutual interaction between students and educators, which involves many components to achieve learning objectives.

As written in constitution Number 20 of 2003 concerning the National Education System, that: Learning is an effort made to obtain the competence of knowledge, skills, and attitudes needed in doing a job. Therefore, in learning students need to be equipped with critical thinking skills that can be used to analyze and solve problems they will face in everyday life, one of them is in thematic learning. To improve students' abilities, teachers should use several learning media. The selection of an appropriate learning model will facilitate the Educator in achieving learning objectives. According to Komalasari (2010: 58-88), there are several types of learning models, namely: Problem Based Learning Models, Cooperative Learning Models, Project Based Learning Models, Service Learning Models, Work-Based Learning Models, and Concept Learning Models, and Value Learning Models.

Based on several types of learning models researchers will use the Problem Based Learning learning model, this is based on the strengths of the Problem Based Learning learning model such as students better understanding the concepts being taught, involving actively solving problems and demanding higher student skills and embedded knowledge based on the schema owned by students so that knowledge is more meaningful. Tekkaya in Farade, et al (2013: 29), advocates the use of Problem Based Learning as a learning strategy to improve student performance both in cognitive, affective or psychomotor outcomes. According to Barrett \& Moore (in Karami, et al, 2013: 38), Problem Based Learning is learning that helps students to be independent so they can continue to learn to solve their problems throughout their lives.

Learning as well as having more meaningful experiences. According to Dewey in Trianto (2010:91) learning based on problems is the interaction between stimulus and response, a relationship between two-way learning theory and the environment. The intended interaction is communication in forming a learning collaboration to understand the concept of learning. According to Sumantri (2016: 145), through the use of communication technology in learning students are able to develop varied learning experiences, giving birth to a pleasant atmosphere for students by using images in communication technology can stimulate students to want to know more about the contents of a lesson, so that children become more diligent and triggered to learn to concentrate and help improve the effectiveness and efficiency of the teaching and learning process. Furthermore, Solihatin (2012: 36) argues that communication is a process, not a static thing. Communication produces a change in an 
effort to achieve results, involves mutual interaction and involves a group.

In learning using the Problem Based Learning technique, students' communication skills are trained through small group discussions about daily activities at home. Based on the results of interviews with elementary school educators in Darma Bangsa School, it turns out that most of the educators in the school only use textbooks during learning activities and do not use any media in learning. Based on these problems, resulting in active and full-time students learning activities take place, the learning process seems monotonous so that learning success is low. Based on observations and interviews with the second-grade educators of Lampung Nation Elementary School that the learning process on thematic material, students have not been able to learn independently and actively because they still depend or need the help of educators in their learning. As a result, students cannot find thematic learning outcomes.

Based on the needs analysis at Bandar Lampung Darma Bangsa Elementary School, it shows that the majority of educators have not used teaching materials in the media. Most of the educators indicated that the average percentage score answered "Yes" and "agreed" when teaching materials were developed in the form of image media based on Problem Based Learning, so as to help students play an active role in learning and be responsible for understanding the concepts of the material presented. So researchers are interested and feel the need to improve learning so that student learning outcomes can be improved.

\section{RESEARCH METHODS}

The type of research using research and development refers to the theory of Borg \& Gall (1983: 772) on ReasearchBased-Development according to the purpose of research, namely research procedures with the aim of developing and validating educational products developed. Borg and Gall (2003: 569-575) research and development procedures, namely research and information collecting, planning, developing preliminary form of product, preliminary field testing, main product revision, playing field testing, operational product revision, operational field testing, final product revision, and dissemination and implementation. The research and development carried out only reached the seventh step, because of the limitations of researchers, both in terms of time and cost.

The sample was determined by purposive sampling of 16 students of second-grade at Darma Bangsa Elementary School. Data collection tools for the development Image Media Based On Problem Based Learning tools using a questionnaire, namely the validation of curriculum and learning experts covering aspects of material, design, and picture.

Data collection tool for developing Of Image Media Based On Problem Based Learning To Grow Communication Skills using a questionnaire, namely expert validation that includes aspects of material, design, and picture to test the feasibility and attractiveness. Learning outcomes are obtained from the results of the pretest and posttest learning using LKS Of Image Media Based On Problem Based Learning appraisal, using valid and reliable test instruments, and considering the level of difficulty and different power of questions. The multiple choice instrument is given a score of 1 for the correct answer and a score of 0 for the wrong answer. Learning outcomes of skills using observation sheets. The n-gain analysis that will be used in this study is based on the results of the pre-test and post-test. Hake (in Sundayana, 2015: 149) revealed that in order to know the effectiveness of a learning in conceptual understanding, an analysis of the average value of normalized gain was carried out.

\section{RESEARCH RESULTS AND DISCUSSION}

The results of the research and development of image media based on Problem Based Learning to foster student communication skills, obtained the following results.

\subsection{Research and Information Collection}

Information was collected by observation and interviews with the school principal and second-grade teacher at the Darma Bangsa School. Requirement analysis, which is conducting a needs analysis for the purpose of the product to be developed. This stage aims to aim at the product to be developed. This stage aims to determine the existence of a situation that should exist with real conditions on the actual field. In addition, the writer also identified appropriate Core Competencies and Basic Competencies, describing Core Competencies and Basic Competencies into indicators in the form of work or operational goals. Based on the needs analysis in Darma Bangsa Elementary School Bandar Lampung, the problems obtained in broad outline indicate that the educator has not used instructional media in learning.

\subsection{Planning (Planning)}

Planning is done by analyzing the results of information gathering. The product to be developed is in the form of a learning device consisting of a syllabus, Learning Implementation Plan, image media, and assessment instruments. Furthermore, the authors systematically compile the basic competencies, indicators, and learning objectives developed in this study on the specified themes and sub-themes. 


\subsection{Initial Product Format Development}

The steps in the development of Pimage media based on Problem Based Learning products are as follows.

\section{a. The preparation of image media products based on Problem Based Learning}

The teaching material product that was developed was the image media for learning in the second-grade of Darma Bangsa Elementary School). Here is a prototype that was compiled. Syllabus, Learning Implementation Plan, and products (Cover, Preface, Table of Contents, Basic Competency Mapping, Instructions for Use, Material and Activity Description, Evaluation, Bibliography) and Test Instruments.

\section{b. Product Validation and Product Revision}

Product validation is carried out by curriculum experts to assess the validity of teaching materials. Next is the learning expert, namely material expert and media expert, to assess whether Problem Based Learning based on image media will be valid and effective to improve communication skills and student learning outcomes. The first is the expert material assessment, this assessment includes the assessment of learning tools in the form of syllabus and Learning Implementation Plan conducted by Lecturers at the University of Lampung. Based on the material expert test, several things need to be improved, namely (1) learning steps must refer to Problem Based Learning, (2) time allocation must be adjusted to the division of class hours, and (3) writing on the syllabus matrix, indicators must parallel to basic competencies. Secondly, expert learning assessments conducted on image media based on Problem Based Learningproducts consisting of design experts and media experts. The two experts are Lecturers at the University of Lampung. Based on the learning expert test, in general, several things need to be improved, namely (1) the cover is designed to be more attractive, (2) core competency needs to be added, and (3) the rice plant flow scheme in the material description needs to be clarified.

\subsection{Preliminary Field Testing}

For the limited test conducted in the second-grade lovely Darma Bangsa Elementary School Bandar Lampung, namely the trial of getting the results of the first $80 \%$ students answered "Yes", the second $85 \%$ students answered "Yes" and the third Student answered 95\% answered "Yes" on average the overall score was $86.66 \%$ using a scale based on (Guttman, L.: 1944). This shows that the image media that have been developed are interesting, easy and useful to use. Then for the small group trials that are still carried out in lovely second-grade namely the results of the test of attractiveness, convenience and usefulness obtained 3.14\% results for aspects of attractiveness with very interesting statements, $3.25 \%$ for convenience with easy statements, and $3.25 \%$ with a statement of very useful for aspects of usefulness. The results of the analysis showed that in general the attractiveness of image media with very interesting criteria, ease of learning using image media showed easy results and the use of image media in learning got very beneficial results, so it was feasible to be used as Thematic learning material in second-grade.

The next test is the effectiveness test of the use of individual image media, the effectiveness of using image media based on Problem Based Learningmodel can be operated from the pre-test and post-test values calculated by the N-Gain formula. Based on the results of the above hypothesis test, the N-Gain value is 0.4193 and students who reach the Minimum Mastery Criteria value is $80 \%$ then the image media based on Problem Based Learningmodel is quite effective and feasible to be used in the next test as a guide to thematic learning as a group.

\subsection{Main Product Revision}

Small group trial data shows that the image media based on Problem Based Learning models in thematic learning is very interesting, easy, and useful. In the learning activities too, students are so enthusiastic in following it, so that at the end of learning students understand the dynamics of the learning process. Based on the results of the questionnaire, the students considered that learning media were good, as a whole there was no need to revise the image media based on Problem Based Learningmodel, on Thematic learning because there were no suggestions for improvement in image media.

\subsection{Main Field Testing}

A trial of expanded field use is carried out using products in the field to see the advantages and disadvantages of image media that have been widely developed. This field use trial was conducted in second-grade Friendly as many as sixteen students, to find out the attractiveness, ease, and usefulness and to find out the effectiveness of the image media that was created. The results of the field trials were extended to the results of the test of attractiveness, convenience, and usefulness as follows;

Table 1 Tests of attractiveness, convenience, and deficiencies

\begin{tabular}{|l|l|l|l|}
\hline NO & Test Type & Average Score & Qualitative Statement \\
\hline 1 & Attractivenes of image media & 3,38 & Very interesting \\
\hline 2 & Easyness of image media & 3,40 & Very easy \\
\hline 3 & Expediency of image media & 3,26 & Very useful \\
\hline
\end{tabular}

Based on the results of the attractiveness of the image media questionnaire, a score of 3.38 was obtained with the category "Very Attractive" which was assessed from the aspect of the appearance and content of the image. In 
the aspect of displaying the use of colors, image shapes, and visualization of images is appropriate and very interesting to learn. The colors used in image media use bright and varied colors so that learning to use image media is not easily bored. Based on the results of the convenience questionnaire obtained a score of " 3.40 " with the category "Very Easy", which was assessed from this aspect is the clarity of the image media, the flow of presentation of the image media as well as the clarity of material exposure on the image media.

The contents of the contents in the image media are very detailed to clarify the material being studied. The plot of image media agreement is also very detailed so that it is easily understood by students, furthermore, the clarity of material exposure in the media using images is also more interesting for students to learn in secondgrade so that the problems contained in learning can be solved by students. Furthermore, the results of the usefulness questionnaire, obtained results 3.26 with the category of "Very Benefits" assessed from the aspect of function, which helps increase student interest in understanding learning material because the subject matter taught is arranged using the Problem Based Learning model, so students play an active role in the process learning by using image media developed by the guidelines contained in the image media, and most importantly with the media model Problem Based Learning model, students are more careful together with members of the group in solving everyday problems because students understand more about the material they are learning. The results of the analysis show that in general the attractiveness, convenience, and usefulness of image media are very well used as Thematic learning materials. For the results of the effectiveness of image media obtained from the pre-test and post-test values, the results are seen in the table below

Table 2. N-Gain Test Results

\begin{tabular}{|l|l|l|l|}
\hline \multirow{2}{*}{ Information } & \multicolumn{2}{|c|}{ Score } & \multirow{2}{*}{ N-Gain } \\
\cline { 2 - 3 } & Pre-test & Post-test & \\
\hline Average & $\mathbf{7 5 , 4 3}$ & $\mathbf{8 6 , 8 7}$ & $\mathbf{0 , 4 8 8}$ \\
\hline
\end{tabular}

Based on the results of the N-Gain hypothesis test of 0.488 and students who achieved the value above the Minimum 75 Completion Criteria is $80 \%$, then the image media based on Problem Based Learningmodel in thematic learning is quite effective and feasible to be used as a Thematic learning guide. After that the normality test and also the test of the difference in the use of image media, the results of the pre-test and post-test values are then tested for normality using the Kolmogorov-Smirnov test with the hypothesis:

Ho: sample data is normally distributed

Ha: sample data is not normally distributed

Test results (data attached) show that the data are normally distributed. This is supported by the Asymp. Sign value (2-tailed) for the pre-test value of 0.809 (above 0.05), meaning Ho is accepted. Likewise, Asymp.Sig. Value (2-tailed) for the average Post-test value of 0.965 (above 0.05), means that Ho is accepted. Data that have been normally distributed are then used to test differences in learning outcomes before and after the use of media Data were tested using Paired Sample T-Test, with test hypotheses:

Ho: There is no difference in learning outcomes before and after the use of the Media Image Problem Based Learning model in Thematic learning

Ha: There are differences in learning outcomes before and after the use of image media based on Problem Based Learningmodels in Thematic learning.

With decision-making criteria:

If $\mathrm{Sig}>\mathrm{Ho}$ is accepted

If Sig $<$ then Ho is rejected

Paired Sample T-Test (attached data) shows that the Sig. (2-tailed) value for the pre-test and post-test values is 0.00 below 0.05 ( $\mathrm{sig} 0.000<0.05$ ), meaning Ho rejected and Ha accepted. Based on these results, there are differences in student learning outcomes before and after the use of of image media based on Problem Based Learningmodels in the second-grade thematic learning at Darma Bangsa Elementary School.

\subsection{Operational Product Revision}

After the main field trials done to improve the product, it was revised with regard to comments and suggestions during the previous trial.

\subsection{DISCUSSION}

The purpose of this study is to produce aimage media based on Problem Based Learning in the thematic learning of second-grade elementary school by using the Borg \& Gall development procedure (Sugiyono, 2015: 298), Knowing the attractiveness of image media based on Problem Based Learning to improve communication skills in the learning of participants in second-grade elementary schools, and know the level of effectiveness of image media based on Problem Based Learning to improve students' learning communication skills. Research that is relevant to this research is "Development of Module Based on Problem Based Learning to improve Student Communication Capabilities" and "Effect of Problem Based Learning Models on Communication Capabilities of the students atSenior High School 15 Bandar Lampung", both studies have the results that the communication 
skills of students at the class that uses the Problem Based Learning model are better than the control class, and the Problem Based Learning model is very influential on the learning outcomes of the cognitive aspects.

While the research development stage uses ADDIE instructional design (Sugiyono, 2015: 38) with 5 stages, namely: (1) Requirement analysis, which is conducting a needs analysis for the product to be developed. This stage aims to aim at the product to be developed. This stage aims to determine the existence of a situation that should exist with real conditions on the actual field. Besides, the writer also identified appropriate Core Competencies and Basic Competencies, describing Core Competencies and Basic Competencies into indicators in the form of work or operational goals. (2) Designing image media based on Problem Based Learningin second-grade thematic learning, namely the process of designing image media based on Problem Based Learning media based on the appropriate Core Competencies and Basic Competencies. (3) Creating image media based on Problem Based Learningin Thematic learning second-grade, namely analyzing the Core Competencies and Basic Competencies on the curriculum content standards in 2013. After the Core Competencies and Basic Competencies are adjusted then the image media based on Problem Based Learning models are made in the appropriate Thematic learning with user usage. (4) Implementation of the development of the image media based on Problem Based Learningin thematic learning, which is the implementation stage in the field. (5) Product evaluation and dissemination is the stage of evaluating each stage of the implementation and use of the image media based on Problem Based Learningmodel so that students become more interested in learning in thematic learning, easy to understand the concepts presented and can be utilized and effectively used as a learning medium that invites students to together to think more actively and critically when using it. The next stage, after the initial product image model Problem

Based Learning model, is made then a product validation test is performed. After getting suggestions for improvement, a revision was made and a product that was worth using was obtained. In the next stage to find out the attractiveness, ease and usefulness, a one-on-one, one-person, small-group trial, and an expanded usage test were conducted. In one-on-one individual tests conducted to identify the extent to which the image media can be used easily by students. Based on the questionnaire, the results of the one-on-one test found that students were able to use imagemedia and obtained an average percentage score of $86.6 \%$. This shows that the image media that have been developed are interesting, easy, and useful to use. Whereas the small group trial is used to find out the attractiveness, ease, and usefulness of image media products. A questionnaire is given after students use the image media used during learning. Based on the results of the attractiveness questionnaire, a score of 3.41 was obtained with the "very interesting" category, which was assessed from the aspect of image media display. For the quality of the ease of learning, image media obtained a score of 3.25 with the category of "easy" assessed from the aspect of image clarity, the flow of presentation of images, and the clarity of the use of images and also the clarity of material exposure.

The quality of usefulness obtained 3.27 with the category "very useful" from the aspect of function helps increase students' interest in understanding learning material easily. Based on the results of the one-on-one test questionnaire and a small group test of attractiveness, convenience, and overall usefulness, it does not need to be revised the image media based on Problem Based Learning model in the thematic learning of second-grade elementary schools, because there is no suggestion for improvement of the image media. Furthermore, the expanded usage test obtained based on the results of the attractiveness questionnaire obtained a score of 3.38 with the category "very interesting", which was assessed from the aspect of the appearance of the image media. In the aspect of the appearance of the image media the use of images, the shape of the image and the colors used are bright so that it makes the image media more interesting and does not make students bored to learn it. Based on the results of the convenience questionnaire, a score of 3.40 was obtained with the category of "very easy" which was assessed in terms of the clarity of the image, the flow of the image presentation, and the clarity of the use of the image and also the clarity of the material exposure.

The flow of presentation in the image media is made very easy so it is easy to understand. Furthermore, the clarity of the image is made by the material so that it is easy for users to understand, instructions in the image media are also very clear so that students are easy to use and learn the images provided. Based on the results of the usefulness questionnaire, a score of 3.26 was obtained with the category of "very useful", which was assessed from the aspect of function, which helped increase students' interest in understanding the subject matter, because the material taught was arranged using the Problem Based Learning model so students played an active role in the process learning by using image media that is developed by the guidelines, and most importantly with the existence of image media based on Problem Based Learning model, students are more careful individually and with group members in solving daily problems because students understand more about the subjects they are learning. Then based on the results of the field test assessment of the effectiveness of 16 students obtained student learning outcomes that reach the value above the Minimum 75 Completion Criteria is $80 \%$ with an average cognitive value of 86 and an average $\mathrm{N}$-gain value of 0.487 then the image media based on Problem Based Learningmodel in the thematic learning of second-grade elementary school is quite effective and feasible to use as a learning medium. Learning with the Problem Based Learning model makes students aware metacognitively, namely students must be aware of the information that has been known about the problem being faced, the information needed to solve 
these problems, which is by the research development image media of the Problem Based Learning model to encourage the development of knowledge, abilities, and skills of students which results in increased student learning outcomes. According to this explanation, it can be summarized the purpose of this development, producing a product in the form of Problem Based Learning model media in the thematic learning of second-grade elementary school, has been achieved and can be used as media very interesting, very easy to use, very useful, and effective to use.

\section{CONCLUSION}

Based on the research results of the development of the image media based on Problem Based Learningmodel in the thematic learning of the second-grade of the Darma Bangsa Elementary School in Bandar Lampung it can be concluded as follows (1) Image media, PB models; in second-grade thematic learning that has been developed based on the assessment of design experts and material experts declared valid and feasible to use. (2) the image media based on Problem Based Learning model in second-grade thematic learning has a "Very Attractive" attractiveness classification, a "Very Easy" ease classification, a "Very Helpful" usefulness classification according to students. Thus the image media is feasible to be used as one of the learning media. (3) Image media are declared effective and appropriate to be used as learning media based on the increasing average of student learning outcomes that achieve values above the Minimum Mastery Criteria.

\section{REFERENCES}

Borg, W. R. \& Gall, M. D. (1983). Educational research: an introduction (4thed). New York \& Longman Inc. London.

Borg, W.R dan Gall, M.D. 2003. Educational Research an Introduction. Longman Inc. New York.

Farade, Alfred Olufemi, dkk. 2013. "Effect of Problem Based Learning on Senior Secondary School Students' Achievements in Further". Acta Didactica Napocensia, 6 (3): 27-43

Karami, dkk, 2013, Analyzing the Effectiveness of Reward Management System on Employee Performance through the Mediating Role of Employee Motivation Case Study : Isfahan Regional Electric Company. International Journal of Academic Research in Business and Social Sciences.Vol.3 No.9

Komalasari, Kokom. 2010. Pembelajaran Kontekstual, Konsep dan Aplikasi. Refika Aditama: Bandung. Depdiknas. 2003. Undang-Undang No.20 Tahun 2003 tentang Sistem Pendidikan Nasional. Jakarta.

Sugiyono. 2015. Metode Penelitian dan Pengembangan. Alfabeta. Bandung.

Solihatin, Etin. 2012. Strategi Pembelajaran. Bumi Aksara. Jakarta.

Sumantri \& Johar Permana. 2001. Strategi Belajar Mengajar. CV. Maulana. Bandung.

Sundayana. 2015. Statistika Penelitian Pendidikan. Alfabeta. Bandung.

Trianto. 2010. Model Pembelajaran Terpadu. Bumi Aksara. Jakarta. 